Revista Brasileira de Meteorologia, v.25, n.1, 103 - 113, 2010

\title{
CLIMATE FEEDBACKS INDUCED BY THE NORTH ATLANTIC FRESHWATER FORCING IN A COUPLED MODEL OF INTERMEDIATE COMPLEXITY
}

\author{
FLÁVIO BARBOSA JUSTINO E JEFERSON PRIETSCH MACHADO \\ Universidade Federal de Viçosa (UFV), Viçosa, MG, Brasil \\ fjustino@ufv.br,jefpmac@gmail.com
}

Received October 2008 - Accepted October 2009

\begin{abstract}
Based on coupled model simulations (ECBilt-Clio), we investigate the atmospheric and oceanic response to sustained freshwater input into the North Atlantic under the glacial maximum background state. The results demonstrate that a weakening of the thermohaline circulation triggered by weaker density flux leads to rapid changes in global sea-ice volume and reduced poleward heat transport in the Northern Hemisphere (NH). In the Southern Hemisphere (SH), however, the oceanic heat transport increases substantially. This in turn leads to strong cooling over the North Atlantic whereas the SH extratropical region warms up. The suppression of the NADW also drastically changes the atmospheric circulation. The associated northward wind anomalies over the North Atlantic increase the warm air advection from the tropics and induce the transport of tropical saltier water to mid-latitudes. This negative atmospheric-oceanic feedback should play an important role to resume the NADW, after the freshwater forcing ends up.
\end{abstract}

Keywords: Thermohaline circulation, climate changes, baroclinic activity

RESUMO: ANOMALIAS CLIMÁTICAS INDUZIDAS POR UM AUMENTO DE ÁGUA DOCE NO ATLÂNTICO NORTE EM UM MODELO ACOPLADO DE COMPLEXIDADE INTERMEDIÁRIA

Baseado em simulações numéricas realizadas com um modelo acoplado (ECBilt-Clio), investigamse as anomalias atmosféricas e oceânicas associadas ao aumento de água doce no Atlântico Norte sob condições glaciais. Os resultados demonstram que um enfraquecimento da corrente termohalina provoca rápidas mudanças no volume global de gelo marinho, bem como uma redução no transporte de calor em direção ao Hemisfério Norte (HN). No Hemisfério Sul (HS), no entanto, o transporte oceânico de calor aumenta substancialmente. Como resultado, ocorre um forte esfriamento ao longo do Atlântico Norte, enquanto que a região extratropical do HS aquece. A inibição da circulação termohalina também muda drasticamente a circulação atmosférica. Intensas anomalias de ventos da região equatorial induzem um transport de águas quentes e salinas, assim como são associadas com um aumento na advecção de ar quente dos trópicos. Esta interação oceano-atmosfera opõe-se à tendência climática inicial imposta pelo aumento de água doce no Atlântico Norte.

Palavras chave: Circulação termohalina, mudanças climáticas, atividade baroclínica

\section{INTRODUCTION}

Centennial to millennial scale changes in global climate over the last $100 \mathrm{kyr}$ (thousand years before present) were identified in the Greenland Ice Core Project (GRIP). Further analyzes demonstrated that instability mechanisms of the ice sheets around the North Atlantic and of the thermohaline circulation are prime candidates to trigger such changes (Schäfer et al., 2001). Moreover, additional investigations demonstrated that those climate shifts may be also related to freshwater anomalies into the Arctic/Labrador Seas (Peltier et al., 2006; Blunier and Brook, 2001) or into the Antarctica Peninsula (Seidov et al., 2001).

The series of rapid oscillations called DansgaardOeschger events (warm periods) and Heinrich events (cold periods), were associated with local temperature changes 
over Greenland of up to $15^{\circ} \mathrm{C}$ (Lang et al., 1999), within a decade. The cause of these glacial events is still under debate. Currently, the leading hypothesis involves a slowdown of the ocean's thermohaline circulation. Studies have hypothesized that these freshwater dumps reduced ocean salinity enough to slow deepwater formation and the thermohaline circulation. Since the thermohaline circulation plays an important role in transporting heat northward, a slowdown would cause the North Atlantic to cool (MacAyeal, 1993). Many of these swings in the climate system were not just a local phenomenon, but had global impact with evidence in South America (Lowell et al., 1995), the North Pacific (Kotilainen and Shackleton, 1995), Southwest Pacific (Pahnke and Zahn, 2005), the Santa Barbara Basin (Behl and Kennet, 1996), the Arabian Sea (Schulz et al., 1998) and the South China Sea (Wang, 1999). These events are perhaps the most pronounced climate changes that occurred during the past $100 \mathrm{kyr}$. Recently, based on U/Th-dated stalagmite from subtropical southern Brazil, -variations of U/Th are likely related to the intensity of precipitation-, Cruz et al. (2005) demonstrated that the Dansgaard-Oeschger cycles affected the tropical hydrological cycle, but in southern Brazil, millennialscale climate changes are not as dominant as they are in the Northern Hemisphere.

The Thermohaline Circulation (THC) is a key element of the global climate system because it carries a substantial amount of heat and saline waters poleward (Knutti et al., 2004). Climate changes associated with perturbation of the THC have been inferred from paleo-climatic records as well as from model simulations forced by increasing concentration of atmospheric greenhouse gases. Recently, Bryden et al. (2005), based on measurements from ships along a transatlantic section along latitude $25^{\circ} \mathrm{N}$ suggested that the Atlantic meridional overturning circulation has slowed by about 30 per cent, mostly between 1992 and 1998. Climate changes triggered by perturbation of the THC have been extensively documented in high latitudes, more recently evidence has also been put forward on the role of the THC upon tropical climate. Timmermann et al. (2005) demonstrated that sea level fluctuations and thermocline depth in the North Atlantic vary in opposite phase with salinity changes in the tropical Pacific, this raises the possibility that a distinct temporal variability and magnitude of the El-Niño-Southern Oscillation (ENSO) phenomenon may occur in the future, due to changes in the North Atlantic precipitation/evaporation regime.

Based on coupled model simulations, Dahl et al. (2005) provided additional evidence that extreme cold conditions over the North Atlantic linked to weaker THC can lead to a southward displacement of the Intertropical Convergence Zone (ITCZ) to allow for greater heat transport across the equator. Given this, the northeast trade winds intensify and precipitation patterns throughout the tropical Atlantic are altered. In particular, precipitation in Northeast Brazil changes significantly.

Hence, this study addresses the impact of the stationary freshwater inflow into the North Atlantic on the atmosphere-seaice-ocean system based on 5 sensitivity experiments. It has also been argued that model simulations conducted under anomalous deep water formation rate can improve our understanding of climate feature characteristic of stadial periods (e.g. Heinrich events).

\section{THE COUPLED CLIMATE MODEL AND THE NUMERICAL EXPERIMENTS DESIGN.}

The atmospheric component ECBILT (Opsteegh et al., 1998) of our coupled system is a 3-layer model with a quasigeostrophic adiabatic core (Marshall and Molteni, 1993) and a set of physical parametrizations for the hydrological cycle (Held and Suarez, 1978; Opsteegh et al., 1998) with a simplified radiation code. It is a spectral model with T21 triangular truncation, corresponding to an approximate resolution of $5.6^{\circ}$ on both latitude and longitude. The coupled ocean-sea ice model CLIO (Goosse et al., 1999; Goosse and Fichefet, 1999; Goosse et al., 2002) is based on the primitive equations and employs a free surface for the ocean component and thermodynamic/dynamic assumptions for the sea-ice component. A parameterization for vertical mixing (Goosse et al., 1999) is employed that constitutes a simplification of the Mellor and Yamada 2.5-level turbulence closure scheme (Mellor and Yamada, 1982). Furthermore, the ocean model CLIO includes mixing along isopycnals so as to capture the impact of meso-scale eddies on the transport (Gent and McWilliams, 1990) as well as the flow of dense water down topographic features (Campin and Goosse, 1999). The horizontal resolution of the CLIO model is $3^{\circ}$ and there are 20 unevenly spaced vertical levels in $\mathrm{z}$ coordinate in the ocean. The individual models are coupled through fluxes exchanges of momentum, freshwater and heat and the simulations are performed using weak freshwater flux corrections so as to inhibit climate drift (Marotzke and Stone, 1995). The model is computationally efficient such on a 150 -year-long simulation may be performed within a single day.

In order to analyze the climate response to freshwater input, five experiments are performed: a simulation of the present day climate, a simulation focusing on the Last Glacial Maximum (LGM), and three additional freshwater experiments driven by LGM boundary conditions. The freshwater experiments are carried out with different sustained freshwater input (FI), i.e. between $50^{\circ} \mathrm{N}$ and $70^{\circ} \mathrm{N}$ the amount of FI into the North Atlantic was altered adding $0.19,0.38$ and $0.475 \mathrm{~Sv}\left(1 \mathrm{~Sv}=10^{6} \mathrm{~m}^{3} \mathrm{~s}^{-1}\right)$. It represents for each model grid cell an increase of FI up to $0.16 \mathrm{x}$ $10^{-7}, 0.33 \times 10^{-7}$ and $0.42 \times 10^{-7} \mathrm{~Sv}$, respectively $(0.19 \mathrm{FI}, 0.38 \mathrm{FI}$ and $0.47 \mathrm{FI}$ hereafter). The amount of freshwater input is based on previous simulation (Rind et al., 2001a; Manabe and Stouffer, 
2000; Schiller et al., 1997; Manabe and Stouffer, 1997), as well as on observed estimates from either glacial meltwater (Liccard et al., 1999) or ice rafted debris (MacAyeal, 1993). Briefly, the FI experiments may be understood as an increase in precipitation in the North Atlantic region. These simulaltions have been run for 700 years starting from equilibrated LGM climate conditions. The analyses discussed here are based upon the last 300 years of each simulation. The present day and LGM simulations have been discussed in detail in previous studies (Justino et al., 2005; Timmermann et al., 2004) and no purpose will be served to discuss these experiments herein. The LGM run and the FI experiments employ the reconstructed ice sheet topography (ICE-4G) characteristic of 21,000 BP (Peltier, 1994), reduced atmospheric $\mathrm{CO}_{2}$ concentration (200 ppm), and appropriate LGM orbital forcing (Berger, 1978). Moreover, an appropriate LGM vegetation mask is prescribed (e.g. Crowley, 1995), for which the deforested soils and plant cover are replaced by their respective albedos. The incorporation of the influence of the ice sheet albedo increases the surface albedo by more than $60 \%$ in North America and northwestern Europe. In comparison with the predicted present day climate, the LGM simulation exhibits an overall surface cooling except over the North Pacific that is mainly driven by topographically induced modification of the large-scale atmospheric circulation (for details see Justino et al., 2005; Timmermann et al., 2004).

\section{RESULTS AND DISCUSSION}

\section{a. Thermohaline Circulation}

Compared to reality, the ECBilt-Clio overestimates the strength of today's NADW. The simulated present day transport associated with the NADW (24 Sv) is around 30\% larger than

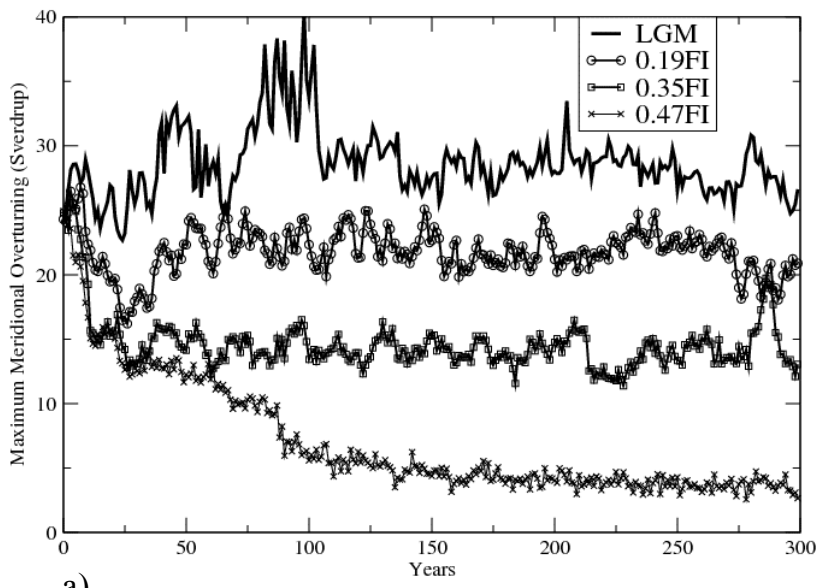

a) that observed (18 Sv) (Talley et al., 2003; Hall and Bryden, 1982). This stronger NADW formation rate is a result of the increased thermal contribution to density changes as well as due to overestimated sea-ice volume and in turn enhanced extratropical surface salinity/brine rejection (Justino et al., 2005). It must be noted, however, that discrepancies associated with the strength of the NADW have been found in models of different complexity, as discussed by Houghton et al. (2001). Compared to the simulated present day NADW, the LGM simulation predicts stronger NADW mainly due to increased vertical air-sea temperature contrast and thus the loss of heat from the ocean to the atmosphere, which leads to the convective mixing intensification. Paleoceanographic data (McCave et al., 1995; Veum et al., 1992) and other LGM model simulations (Hewitt et al., 2001; Kitoh et al., 2001), support the possibility of stronger NADW during the LGM, as those simulated here.

The inclusion of $0.19 \mathrm{~Sv}$ into the North Atlantic, as shown by the 0.19FI simulation, exhibits a slight reduction of the NADW by about $15 \%$ as compared to LGM conditions (Figure 1a). Hereafter the FI anomalies are in respect to LGM conditions. This THC response is similar to the results found by Rind et al. (2001a) that predicted for a freshwater inflow of 0.12 Sv, a $10 \%$ reduction of the NADW. The other FI simulations have shown even larger reductions on NADW formation. Indeed, in the $0.38 \mathrm{FI}$ experiment the NADW diminishes by about 17 Sv which represents a $40 \%$ of reduction compared to the LGM reference run. The changes in the $0.47 \mathrm{FI}$ are even stronger and the NADW shows losses of up to $25 \mathrm{~Sv}$. This represents a reduction of more than $90 \%$ of its strength in the LGM simulation. The weakening of the NADW is accompanied by a strengthening of the Antartic Botton Water (AABW) (Figure 1b). Remarkable, however, is the relative magnitude of the changes in the $0.47 \mathrm{FI}$ run. As a result of the large amount of freshwater

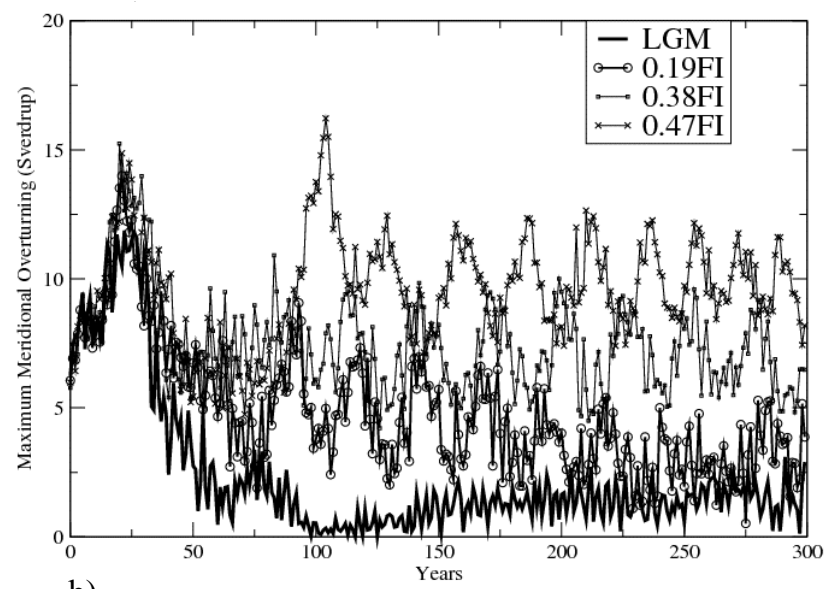

b)

Figure 1 - Time averaged maximum meridional overturning in the North Atlantic for freshwater experiments and LGM run (Sv) (a). And (b) is AABW exported northward at $20^{\circ} \mathrm{S}$ in the South Atlantic for the FI and LGM experiments. 
applied in this simulation, the AABW intensifies by more than $8 \mathrm{~Sv}$. It is twice stronger than that predicted by the present day run and almost four times the LGM counterpart. Modification of the AABW as predicted to occur by the $0.19 \mathrm{FI}$ and $0.38 \mathrm{FI}$ runs are weaker, by about 2 and $6 \mathrm{~Sv}$, respectively. The associated response of the AABW to the amount of freshwater anomalies in the North Atlantic indicates the strong coupling between the Northern and Southern Hemisphere. Nevertheless, it is evident from Figure 1 that AABW experiences much larger amplitude changes compared to those related to the NADW. It should be noted that we are referring to year-to-year variability and not to variations in the mean value.

Changes in surface salinity in the FI experiments in the respective hemisphere are crucial for the weakening of the NADW as well as for the enhancement of the AABW. As proposed by Schmitt et al. (1989) and Speer and Tziperman (1992), surface density anomalies, a combination of thermal and haline density anomalies, can generate thermohaline circulation changes. Compared to the LGM simulation, the FI experiments show a reduction of the thermal density flux due to stronger advection of warm air from the east coast of North America and the North Atlantic region to the Labrador and Nordic seas. In fact, the thermal contrast between the region of NADW formation and the North Atlantic and North America is increased in the FI experiments. This in turn reduces the air-sea temperature contrast and thus the loss of heat from the ocean to the atmosphere, which leads to shallow convective mixing and subsequently weaker NADW formation rate. In addition, the freshwater input reduces the haline density flux which prevents the water to become dense to sink. This happens in the main region of deep water formation (not shown).

Rind et al. (2001b) attributed the strengthening of the AABW to changes in the Antarctic Circumpolar Current
(ACC) and to the longitudinal heat flux divergence out of the South Atlantic. Thus, increase the cooling and sea-ice growth/ salinity amplifying the bottom water production. In part this assumption was found here, because the $0.38 \mathrm{FI}$ and $0.47 \mathrm{FI}$ experiments exhibit higher sea surface salinity (SSS), however, this is not accompanied by a substantial increase in sea-ice and stronger ACC (see Figure 5a). Calculations of the density flux in the $\mathrm{SH}$ show that both the thermal and haline density flux anomalies lead to the AABW intensification (not shown). The FI experiments show large negative heat flux anomalies (i.e. oceanic heat loss) that further increase the thermal density flux. In addition, the reduced precipitation - evaporation flux (by about $10 \mathrm{~m} / 100$ years) strengthens the haline density flux in particular in the Antarctic Peninsula.

\section{b. Atmospheric Circulation}

As proposed by Bjerknes (1964) changes of the poleward heat transport, perhaps associated to distinct NADW formation rate as discussed above, lead to anomalous meridional thermal gradient between equatorial and extratropical latitudes. Indeed, this is depicted by surface temperature anomalies between the FI experiments and the LGM simulation (Figure 2a, b). It is evident that $0.38 \mathrm{FI}$ and $0.47 \mathrm{FI}$ experiments show pronounced cooling in the North Atlantic whereas warmer conditions are predicted in the $\mathrm{SH}$, equatorial oceans and northeastern Pacific. This interhemispheric "seesaw" in the Atlantic Ocean has been found in previous studies (e.g. Knutti et al., 2004; Rind et al., 2001b; Stocker, 1998). The strong cooling in the FI experiments over the North Atlantic and adjacent areas is primary a result of increased sea-ice volume that insulates the atmosphere from the underlying warmer ocean (Peltier et al., 2006). Furthermore, the reduced specific humidity (amount of (a) $0.38 \mathrm{FI}-\mathrm{LGM}$ Surface Temp. Anom.

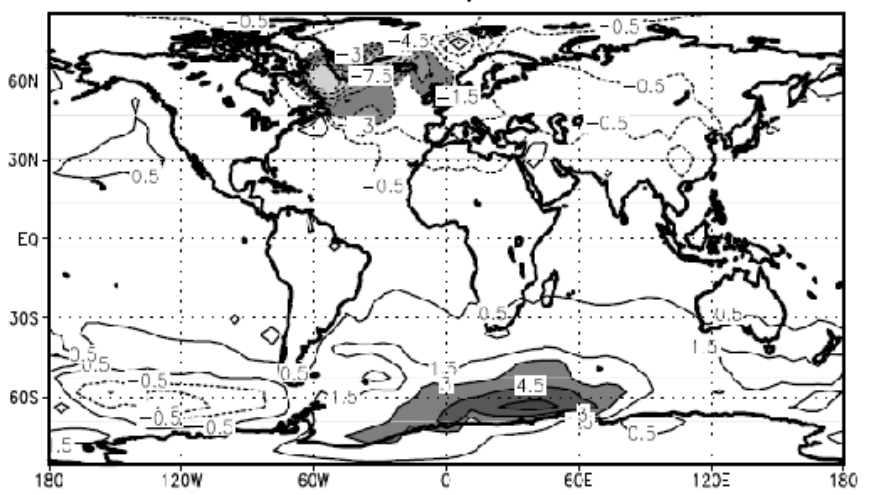

(b) $0.47 F \mid-L G M$ Surface Temp. Anom.

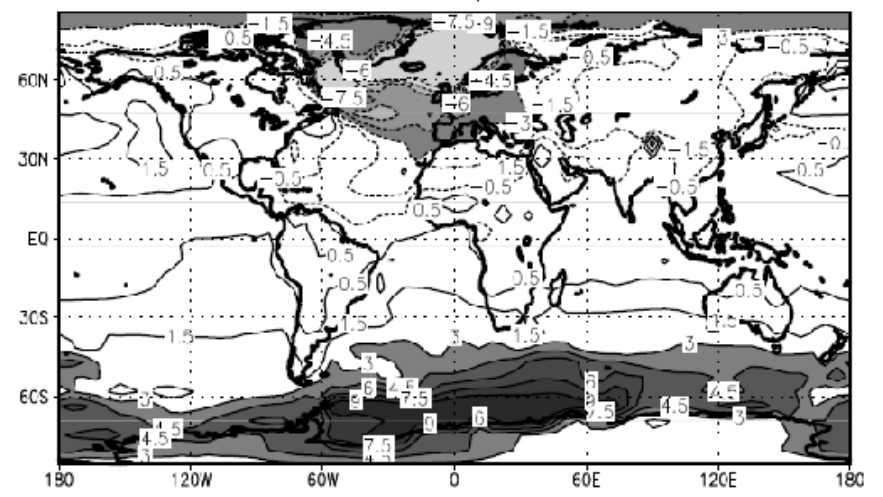

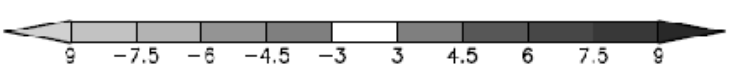

Figure 2 - Time averaged surface temperature anomalies between the FI experiments and LGM run. (a) $0.38 \mathrm{FI}$ (b) $0.47 \mathrm{FI}$. ( ${ }^{\circ} \mathrm{C}$ ). 
water vapor in the air) also plays a key role in cooling the air due to weaker greenhouse capacity of the dryer atmosphere. In the $\mathrm{SH}$, on the other hand, the tropical region experiences a slight warming mainly driven by weaker southeast trade winds and consequently reduced upwelling. It is important to note that surface temperature anomalies over the ocean reproduce changes in sea surface temperature.

Turning to $0.47 \mathrm{FI}$ experiment, one may not that land surface temperature drops to $6^{\circ} \mathrm{C}$ over Greenland and Europe (Figure 2b). This is associated to increased cold advection from the North Atlantic and Arctic Ocean. In addition, the sea-ice/ snow albedo feedback strengthens the amount of solar radiation reflected to the space which produces substantial changes in the surface radiative budget. Over southern North America, however, due to the warmer air blowing from the equatorial region the FI experiments show positive temperature anomalies compared to the LGM run. Over the northeast Pacific the FI experiments exhibit higher surface temperature than those simulated in the LGM run. A similar mechanism responsible for positive surface temperature anomalies between the LGM and the present day climate has been discussed by Timmermann et al. (2004). They argued that SST changes in the North Pacific in the LGM run are primary driven by modifications of the large-scale atmospheric circulation which in turn leads to a reduction of latent and sensible ocean fluxes in the subtropical North Pacific. Moreover, reduced wind stress curl over the Kuroshio area slows down the subtropical and subpolar gyre, cooling down the western North Pacific whereas the northeastern Pacific warms up. Similar features are also found by comparing the FI experiments to the LGM simulation.

(a) Total Heat Transport Atmosphere+Ocean

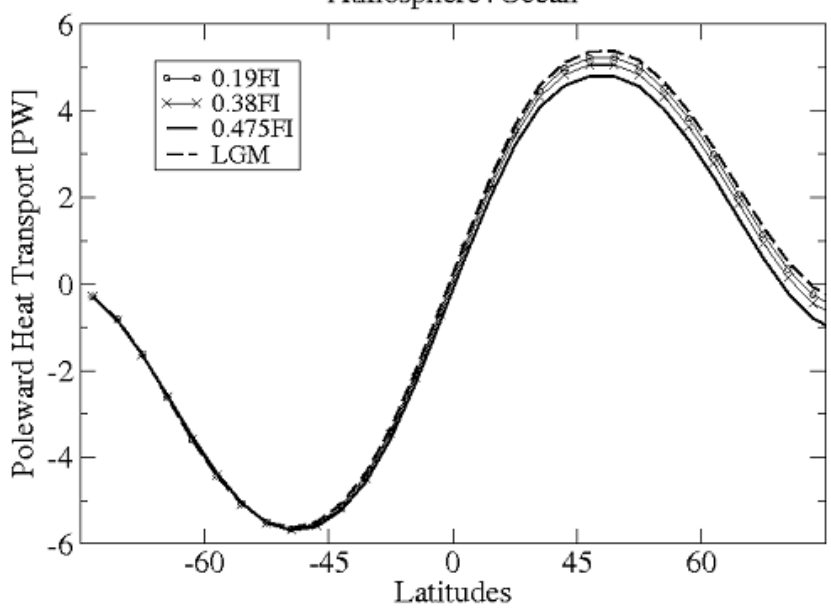

\section{c. Heat Transport}

Although changes in sea surface conditions and atmospheric circulation are crucial to understand climate conditions, it is important to investigate the impact of freshwater forcing upon the oceanic and atmospheric heat transport. The total poleward heat transport of the atmosphere-ocean system in each latitudinal band is computed from the difference between the net shortwave radiation and the outgoing longwave radiative flux at the top of the atmosphere (Peixoto and Oort, 1992). It can be expressed as,

$H(\phi)_{\text {total }}=H_{A T M}+H_{O C E}=2 a^{2} \pi \int_{-\pi / 2}^{\phi}\left(S_{T O A}(\phi)^{\prime}-L_{T O A}(\phi)^{\prime}\right) \cos \phi^{\prime} \cdot d \phi^{\prime}$

$H_{\text {total }}, H_{\text {atm }}$ and $H_{\text {oce }}$ are the total, atmospheric, and oceanic heat transport, $a$ is the radius of the Earth, $\phi$ is the latitude, $S_{\mathrm{toa}}$ is the zonally net shortwave radiation, and $L_{\mathrm{toa}}$ is the zonally outgoing longwave radiation. Both fluxes are computed at the top of the atmosphere.

The simulated present day total heat transport is reasonably simulated as compared to calculations based upon observed data (Trenberth and Caron, 2001; Peixoto and Oort, 1992). The maximum poleward heat transport appears in both hemispheres around $45^{\circ} \mathrm{N}$ and $45^{\circ} \mathrm{S}$ and attains maximum values of 5.2 $\mathrm{PW}\left(\mathrm{PW}=10^{15} \mathrm{~W}\right)$ (Justino, 2004).

Compared to the LGM simulation, the $0.47 \mathrm{FI}$ and $0.38 \mathrm{FI}$ runs show a reduction in the heat transport maxima in the $\mathrm{NH}$ of about $1 \mathrm{PW}$ and $0.5 \mathrm{PW}$, respectively (Figure 3 ). In the $\mathrm{SH}$ comparison among the simulations do not show significant

\section{(b) Oceanic Heat Transport}

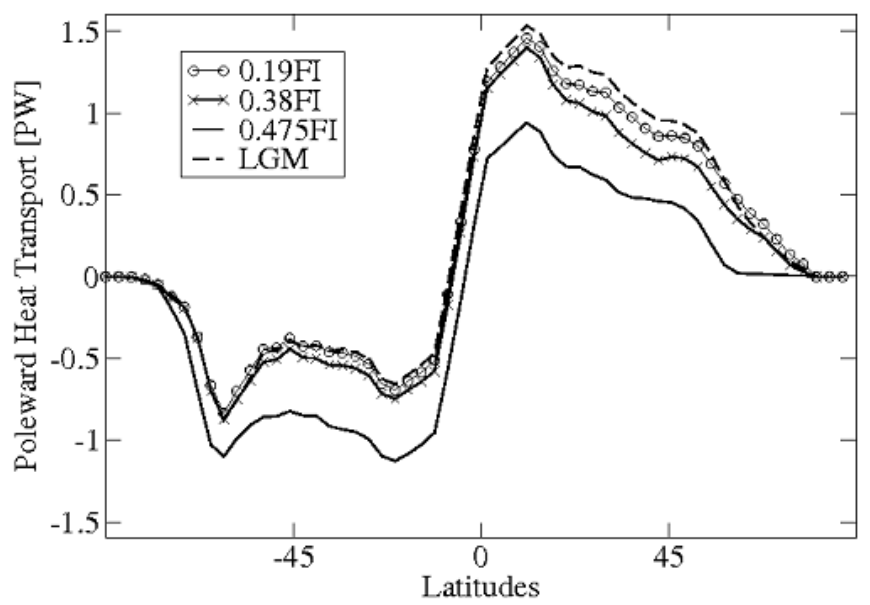

Figure 3 - Time averaged total heat transport (atmosphere + ocean) for the LGM and FI experiments (a). And (b) the oceanic heat transport (PW). 
changes. Increased freshwater into the North Atlantic clearly affects the oceanic heat transport (Figure 3b). It is evident the substantial reduction (increase) of the northward (southward) heat transport in the FI experiments. For instance, at $30^{\circ} \mathrm{N}$, in comparison to the LGM simulation, the oceanic heat transport is reduced by $0.63(0.25) \mathrm{PW}$ in the $0.47 \mathrm{FI}(0.38 \mathrm{FI})$ simulation (Table 1). One should note that under present day and LGM conditions the vertically integrated oceanic heat transport in the Atlantic at $30^{\circ} \mathrm{S}$ is southward. This led to the assumption that sea surface temperature (SST) in the southerm Atlantic is tightly controlled by the magnitude of the NADW (Stocker and Jonhsen, 2003).

It is interesting to note, however, the enhancement of the oceanic heat transport in the North Pacific, which on global basis diminishes the cooling tendency induced by the Atlantic Ocean (Figure 4b). The appearance of northward heat transport in the North Pacific may indicate the action of strong convection, and therefore, the presence of thermohaline-induced meridional overturning.

(a) Oceanic Heat Transport

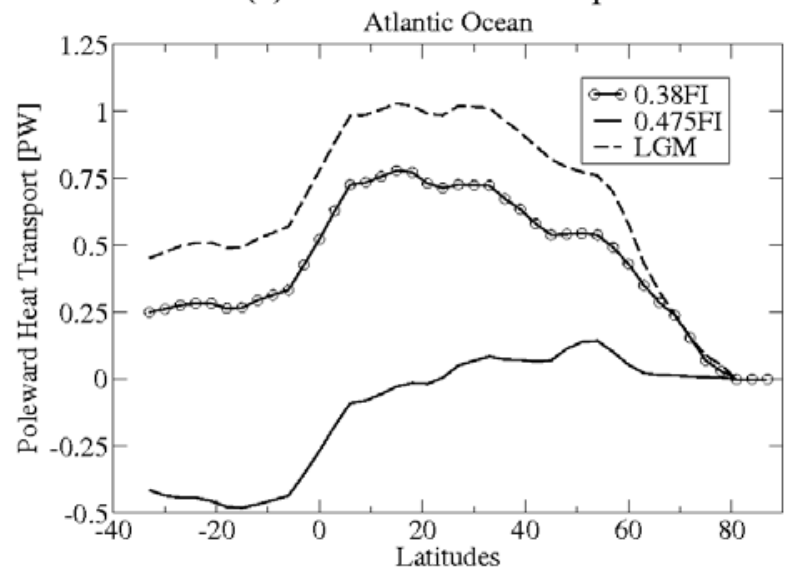

In the $\mathrm{SH}$, the southward oceanic heat transport anomalies induce, in the $0.47 \mathrm{FI}$ experiment (Figure 4a), higher SH extratropical surface temperature as compared to the LGM run. In fact these conditions are associated with accumulated oceanic heat in the SH, since the weakening of the NADW reduces the heat that would be transported northward (Stocker and Johnsen, 2003; Stocker, 1998).

Changes of atmospheric and oceanic circulations have also a large impact upon the oceanic salt transport due to induced wind-driven circulation anomalies. Compared to the LGM, the FI experiments show strong northward salt transport in the North Atlantic. The maximum northward salt transported in the LGM run attains values of $5 \mathrm{psuSv}$ around $45^{\circ} \mathrm{N}$, though it increases up to 16 and $18 \mathrm{psuSv}$ in the $0.38 \mathrm{FI}$ and $0.47 \mathrm{FI}$ experiments (Figure 4c). Furthermore, one may note the reduction of the southward salt transport. These salt transport anomalies opposes the North Atlantic freshening induced by the freshwater forcing. According to the Bjerknes assumption (Bjerknes, 1964), modifications of the meridional thermal gradient in the

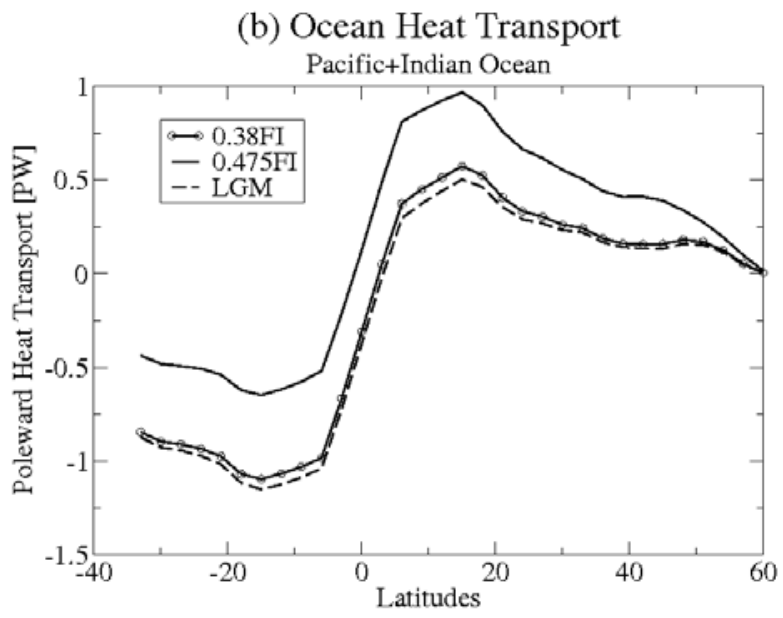

(c) Poleward Salt Transport

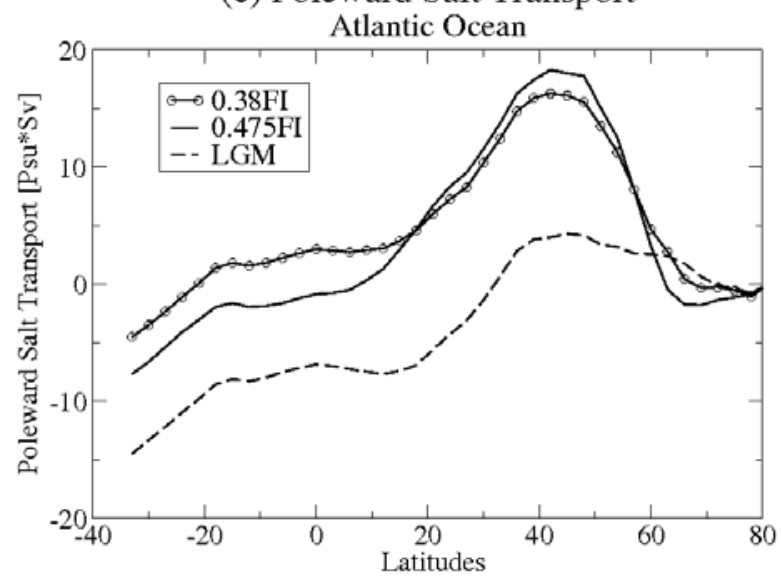

Figure 4 - Time averaged oceanic heat transport (PW) for the LGM and FI experiments in Atlantic (a), Indian/Pacific sector (b). (c) is the poleward salt transport in Atlantic (psuSv). 
atmosphere (ocean) should lead to a reorganization of oceanic (atmospheric) conditions to compensate the reduction in the poleward energy transport. This avoids the continuos cooling of the polar region as well as inhibits a substantial warming in the tropics. Despite the importance of the ocenic heat transport, it is clear based upon Table 1 that the atmosphere plays the leading role on the total meridional heat transport at $30^{\circ} \mathrm{N}$.

\section{d. Interhemispheric Seesaw}

One of the most important findings in the study of millennial-scale climate events is the out-of-phase climate response of the two hemispheres - the interhemispheric seesaw. Broecker (1998) suggests that for rapid climate changes to be initiated there must be a trigger for a sudden "switching off" or

Table 1: Time averaged heat transport at $30^{\circ} \mathrm{N}$ for the FI experiments and the LGM run (PW). The atmosphere heat transport is calculated as the difference between the total heat transport and the oceanic contribution.

\begin{tabular}{c|ccccc}
\hline Experiments & Total Heat & Global Ocean & Atl. & Indi./Pac. & Atmosphere \\
\hline LGM & 5.17 & 1.25 & 1.01 & 0.24 & 3.92 \\
$0.19 \mathrm{FI}$ & 5.01 & 1.13 & 0.87 & 0.26 & 3.88 \\
$0.38 \mathrm{FI}$ & 4.84 & 1.00 & 0.72 & 0.28 & 3.84 \\
$0.47 \mathrm{FI}$ & 4.56 & 0.62 & 0.06 & 0.56 & 3.94 \\
\hline
\end{tabular}

(a) Sea Ice Volume

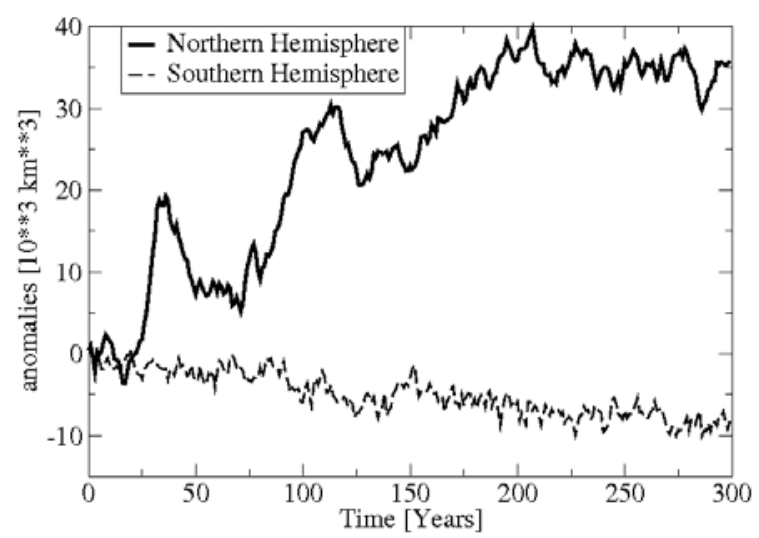

(b) Surface Temperature

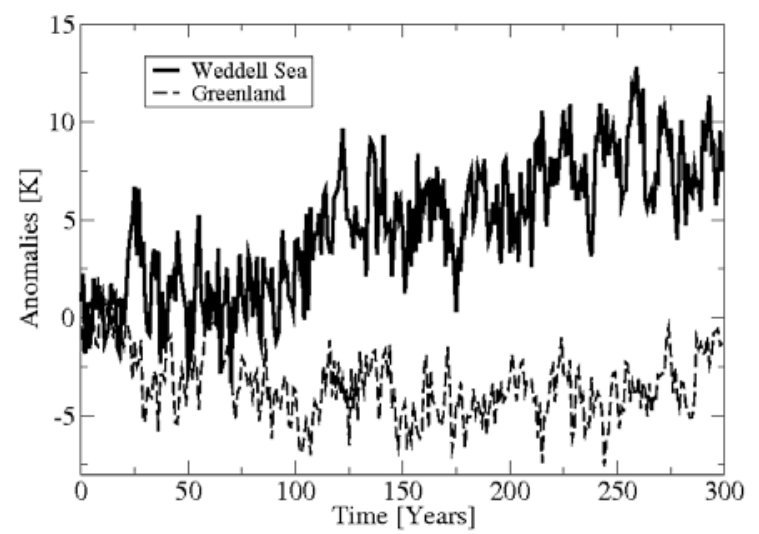

(c) Heat Transport

Atlantic Ocean

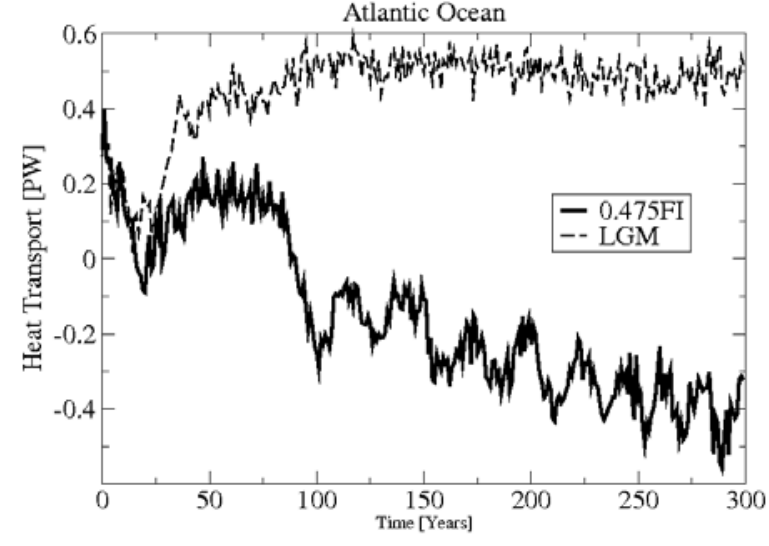

Figure 5 - Time evolution of sea-ice volume anomalies between $0.47 \mathrm{FI}$ experiment and LGM run $\left(103 \mathrm{Km}^{3}\right)(\mathrm{a})$, and Surface temperature $\left({ }^{\circ} \mathrm{C}\right)$ in Greenland and Weddell Sea (b). (c) is the time evolution of the northward heat transport in Atlantic at $30^{\circ} \mathrm{S}$ (PW). 
a strong decrease in the rate of deep water formation in either the North Atlantic or the Southern Ocean. This must be due to a density decrease on the surface water. Changes of the density could result from changes in salinity (changes in freshwater) and/or increased temperatures. The predicted interhemispheric or bipolar seesaw in the FI experiments is shown in Figure 5. It exhibits rapid changes of sea-ice volume in the NH (Figure 5a) which leads to cooling over Greenland (Figure 5b). It is interesting to note the strong link between the changes in surface temperature in Weddell Sea and the heat transport anomalies at $30^{\circ} \mathrm{S}$ (Figure $5 \mathrm{~b}, \mathrm{c}$ ). By increasing the heat transport in the South Atlantic by $0.8 \mathrm{PW}$, the surface temperature over Weddell Sea increases by about $10^{\circ} \mathrm{C}$ in a period of 300 years. This in turn reduces the sea-ice volume in the Southern Hemisphere (Figure 5a). In a recent study Knutti et al. (2004) showed that

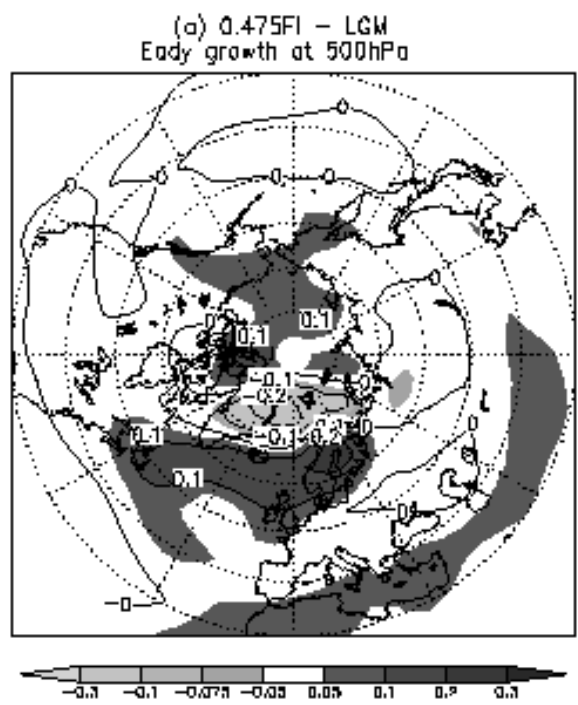

(c) TKE anomalies $\mathrm{NH} 200 \mathrm{hPo}$ C.47FI-LGME

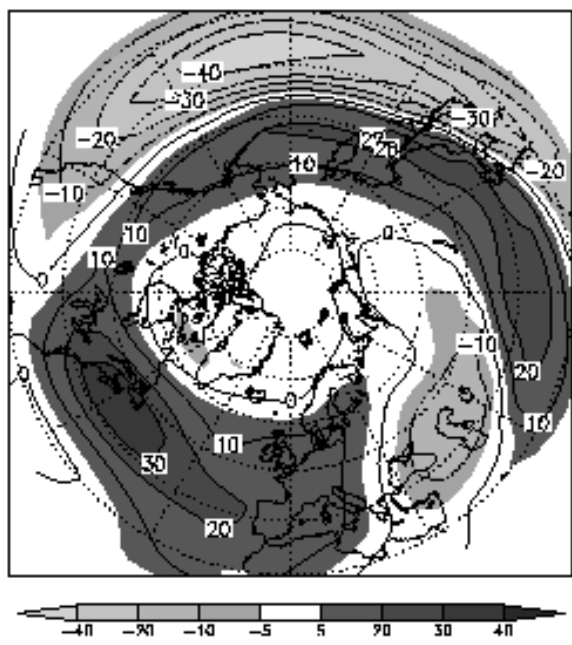

the amount of freshwater discharge into the North Atlantic in addition to a reduction in the THC, has a direct impact on Southern Ocean temperatures.

\section{e. Baroclinic Instability and Total Kinetic Energy}

To investigate changes in baroclinicity induced by anomaly freshwater forcing is shown in Figure 6 the Eady growth rate $\left(\sigma_{\mathrm{B} 1}\right)$. This is a simple measure of the atmospheric baroclinicity that can be employed to quantify the potential for instability and cyclone growth (Lindzen and Farrell, 1980). The Eady growth rate estimates baroclinic instability through the vertical wind shear and the static stability in the atmosphere. It is defined as $\sigma_{B 1}=0.31 \frac{f}{N}|\partial V / \partial Z|$ where $f$ is the Coriolis parameter, $N$ the Brunt-Väisälä frequency, $Z$ the upward

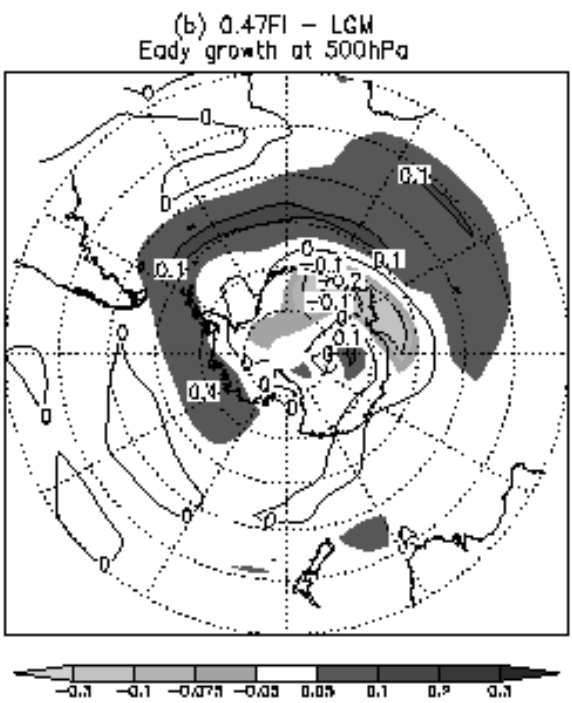

(d) TKE anomalies $5 \mathrm{H}$ 20OhPo

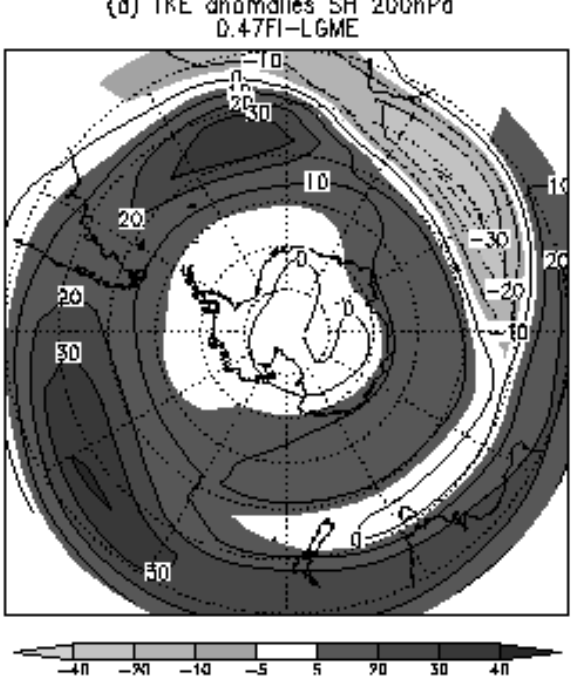

Figure 6 - Time averaged Eady growth rate anomalies between 0.47FI and LGM (a) NH, and (b) SH (Day ${ }^{-1}$ ). (c) and (d) is the same as (a) and (b) but for the total kinetic energy anomalies at $200 \mathrm{hPa}\left(\mathrm{m}^{2} \mathrm{~s}^{-2}\right)$. 
vertical coordinate and $V$ the horizontal wind. The differences between the FI experiments and the LGM are shown in Figure $6 \mathrm{a}, \mathrm{b}$. As expected, the cooling over the North Atlantic/northern Europe induced by enhanced freshwater forcing increases the meridional thermal gradient/vertical wind shear which subsequently produces stronger baroclinic activity (higher $\sigma_{\mathrm{B} 1}$ ) over that region (Figure 6a). It is interesting to note that slight changes are found over the North Pacific due to temperature anomalies between the FI experiments and the LGM run (Figure $2 \mathrm{a}, \mathrm{b})$. Homogeneous warming in the $\mathrm{SH}$ also leads to changes of the baroclinic activity over the ACC area (Figure 6b).

Changes in the baroclinic structure of the atmosphere are tightly linked to anomalies in the mean wind, stationary and transient eddies (or commonly known as storm tracks). In the following, an initial analysis of the subtropical and polar jets is provided by calculating the upper level total kinetic energy

$$
\left[T K E=\frac{1}{2}\left(\overline{u^{2}+v^{2}}\right)\right] .
$$

In the $\mathrm{NH}$ is evident an intensification and a northward shift of the maximum TKE (Figure 6c). Over the North Atlantic this reflects the enhancement of the steady components of the jet stream. This strong jet stream plays an important role in reducing the seasonal zonal thermal contrast in mid-latitudes by coupling the large oceanic heat reservoir to much smaller terrestrial one (Schneider, 1996). Over the North Pacific the dynamical cause of TKE anomalies are more complicated. Due to the weaker subtropical jet, a belt of reduced TKE is found around $30^{\circ} \mathrm{N}$. Also, as a result of the stronger polar jet, the TKE enhances over polar latitudes (Figure 6c). In the SH, the TKE strengthens around Antarctica with two maxima over Atlantic and Pacific Oceans, but weaker TKE is found over the Atlantic/Indian Ocean sector in mid-latitudes.

\section{SUMMARY AND CONCLUDING REMARKS}

Based upon an equilibrated climate driven by LGM boundary condition it is found that the NADW production rate is approximately proportional to the amount of freshwater inflow in the North Atlantic (Rind et al., 2001a; Manabe and Stouffer, 1997; Mikolajewicz et al., 1997). The NADW weakening induces lower SST and air temperature in the $\mathrm{NH}$. In the SH, on the other hand, strong warming is accompanied by an increase in the AABW.

It has been demonstred that the THC shutdown leads to weaker oceanic heat transport in the North Atlantic by about 1 PW (see Figure 4a, Table 1). Thus, the most part of the oceanic heat is transported to the South Atlantic, which has its SST and surface air temperature increased. The suppression of the NADW also drastically changes the atmospheric circulation. The associated northward wind anomalies over the North Atlantic increase the warm air advection from the tropics and induce the transport of tropical saltier water to mid-latitudes. This negative atmospheric-oceanic feedback should play an important role to resume the NADW after the freshwater forcing ends up. Furthermore, the analyses here showed that wind anomalies act as a negative feedback to the initial freshwater forcing.

Comparing the FI experiments with proxy data reveals a general agreement. For instance, Grootes and Stuiver (1997) inferred surface temperature in Greenland lower than $20^{\circ} \mathrm{C}$ compared to today, or $3-6^{\circ} \mathrm{C}$ compared to the LGM. Schäfer et al. (2001) argued that the meltwater released during the major iceberg armada led to an entire stop in NADW and intermediatewater production as well as to a reverse pattern of THC, which in turn, reduces the heat transported northward. Therefore, the inferred climate changes from paleo proxy data have been satisfactorily reproduced in our FI experiments discussed here. The comparison with other modeling results, however, is more complicated since the most part of experiments have been set up with present day boundary conditions (Rind et al., 2001a; Rind et al., 2001b; Manabe and Stouffer, 2000; Schiller et al., 1997) while our experiments have been conducted with LGM boundary conditions.

\section{REFERENCES}

BEHL, R.; KENNET, J. Brief interstadial events in the Santa Barbara basin, NE Pacific, during the past $60 \mathrm{kyr}$. Nature, v. 379, p. 243-246, 1996.

BERGER, A. A simple algorithm to compute long-term variations of daily and monthly insolation. Technical Report 18, Institut d'astronomique et de géophysique, Université de Lauvain, 1978.

BJERKNES, J. Atlantic air-sea interaction. Advances in Geophysics, v. 10, p. 1-82, 1964.

BLUNIER, T.; BROOK, E. Timing of millenial-scale climate change in Antarctica and Greenland during the last glacial period. Science, v. 291, p. 109-112, 2001.

BRYDEN, H. L.; LONGWORTH, H. R.; CUNNINGHAM, S. A. Slowing of the Atlantic meridional overturning circulation at 25N. Nature, v. 438, p. 655-657, 2005.

BROECKER, W. Paleocean circulation during the last deglaciation. A bipolar seesaw? Paleoceanography, v. 13, p. 119-121, 1998.

CAMPIN, J.; GOOSSE, H. A parameterization of dense overflow in large-scale ocean models in z coordinate. Tellus, v. 51A, p. 412-430, 1999.

CROWLEY, T. Ice age terrestrial carbon changes revisited.

Global Biogeochemical Cycles, v. 9, p. 377-389, 1995. CRUZ, F. W.; BURNS, S. J.; KARMANN, I.; SHARP, W. D.; 
VUILLE, M.; CARDOSO, A. O.; FERRARI, J. A.; DIAS, P. L. S.; JR, O. V. Insolation-driven changes in atmospheric circulation over the past 116,000 years in subtropical Brazil. Nature, v. 434, p. 63-66, doi: 10.1038/nature03365, 2005.

DAHL, K.; BROCCOLI, A. J.; STOUFFER, R. J. Assessing the role of North Atlantic Freshwater forcing in millennial scale climate variability: tropical Atlantic perspective. Climate Dynamics, v. 24, p. 325-346, 2005.

GENT, P.; MCWILLIAMS, J. Isopycnal mixing in ocean general circulation models. Journal of Physical Oceanography, v. 20, p. 150-155, 1990.

GOOSSE, H.; DELEERSNIJDER, E.; FICHEFET, T.; ENGLAND, M. Sensitivity of a global coupled ocean-sea ice model to the parameterization of vertical mixing. Journal of Geophysical Research, v. 104(C6), p. 13681-13695, 1999.

GOOSSE, H.; FICHEFET, T. Importance of ice-ocean interactions for the global ocean circulation: a model study. Journal of Geophysical Research, v. 104(C10), p. 23337-23355, 1999.

GOOSSE, H.; SELTEN, F.; HAARSMA, R.; OPSTEEGH, J. Large sea-ice volume anomalies simulated in a coupled climate model. Climate Dynamics, v. 10, doi: 10.1007/ s00382-002-0290-4, 2002.

GROOTES, P.; STUIVER, M. Oxygen 18/16 variability in Greenland snow and ice with 10-3 and 10-5 year time resolution. Journal of Geophysical Research, v. C102, p. 26455-26470, 1997.

HALL, M.; BRYDEN, H. Direct estimates of ocean heat transport. Deep Sea Research, v. 29, p. 339-359, 1982.

HELD, I.; SUAREZ, M. A two-level primitive equation atmosphere model designed for climate sensitivity experiments. Journal of the Atmospheric Sciences, v. 35, p. 206-229, 1978.

HEWITT, C. D.; BROCCOLI, A.; MITCHELL, J.; STOUFFER, R. A coupled model of the last glacial maximum: was part of the North Atlantic relatively warm? Geophysical Research Letters, v. 28, p. 1571-1574, 2001.

HOUGHTON, E. J. T.; DING, Y.; GRIGGS, D.; NOGUER, M.; LINDEN, P. V.; DAI, X.; MASKELL, K.; JOHNSON, C. A. Climate Change 2001. The scientific basis. Cambridge Univ. Press., Cambridge, U.K., pps. 881 pp, 2001.

JUSTINO, F. The influence of glacial boundary conditions on the climate system during the Last Glacial Maximum. Ph.D. thesis, Leibniz Institute of Marine Research, Kiel, Germany, 2004.

JUSTINO, F.; TIMMERMANN, A.; KREBS, U.; SOUZA, E. Synoptic reorganisation of atmospheric flow during the last glacial maximum. Journal of Climate., v. 18, p. 28262846, 2005.
KITOH, A.; MUAKAMI, S.; KOIDE, H. A simulation of the Last Glacial Maximum with a coupled atmosphere-ocean GCM. Geophysical Research Letters, v. 28, p. 2221-2224, 2001.

KNUTTI, R.; FLUECKIGER, J.; STOCKER, T.; TIMMERMANN, A. Strong hemispheric coupling of glacial climate through continental freshwater discharge and ocean circulation. Nature, v. 430, p. 851-856, 2004.

KOTILAINEN, A.; SHACKLETON, N. J. Rapid climate variability in the North Pacific Ocean during the past 95,000 years. Nature, v. 377, p. 323-326, 1995.

LANG, C.; LEUENBERGER, M.; SCHWANDER, J.; JOHNSEN, J. $16^{\circ} \mathrm{C}$ rapid temperature variation in central Greenland 70000 years ago. Science, v. 286, p. 934-937, 1999.

LICCARD, J.; TELLER, J.; CLARK, P. Freshwater routing by the Laurentide ice sheet during the last deglaciation. Mechanisms of Millenial-scale Global Climate Change, in AGU Monograph, 1999.

LINDZEN, R.; FARRELL, B. A simple approximate result for maximum growth rate of baroclinic instabilities. Journal of the Atmospheric Sciences, v. 37, p. 1648-1654, 1980.

LOWELL, T.; HEUSSER, C.; ANDERSEN, B.; MORENO, P.; HAUSER, A.; DENTON, G.; HEUSSER, L.; MARCHANT, C. S. D. Interhemispheric correlation of late Pleistocene glacial events. Science, v. 269, p. 1541-1549, 1995.

MACAYEAL, D. Binge/purge oscillations of the Laurentide ice sheet as a cause of the North Atlantic's Heinrich events. Paleoceanography, v. 8, p. 775-784, 1993.

MANABE, S.; STOUFFER, R. Coupled ocean-atmosphere model response to freshwater input: comparison to younger dryas event. Nature, v. 12, p. 321-336, 1997.

MANABE, S.; STOUFFER, R. Study of abrupt climate change by a coupled ocean-atmosphere model. Quaternary Science Reviews, v. 19, p. 285-299, 2000.

MAROTZKE, J.; STONE, P. H. Atmospheric Transport, The Thermohaline Circulation, and Flux Adjustments in Simple Coupled Model. Journal of Physical Oceanography, v. 25, p. 1350-136, 1995.

MARSHALL, J.; MOLTENI, F. Toward a dynamic understanding of planetary-scale flow regimes. Journal of the Atmospheric Sciences, v. 50, p. 1792-1818, 1993.

MCCAVE, I.; MANIGHETTI, B.; BEVERIDGE, N. Changes in circulation of the North Atlantic during the last 25,000 years inferred from grain-size measurements. Nature, v. 374, p. 149-152, 1995.

MELLOR, G.; YAMADA, T. Development of a turbulence closure model for geophysical fluid problems. Reviews of Geophysics and Space Physics, v. 20, p. 851-875, 1982.

MIKOLAJEWICZ, U.; CROWLEY, T.; SCHILLER, A.; VOSS, R. Modelling teleconnection between the North Atlantic 
and North Pacific during the Dryas event. Nature, v. 387, p. 384-387, 1997.

OPSTEEGH, J.; HAARSMA, R.; SELTEN, F.; KATTENBERG, A. ECBILT: A dynamic alternative to mixed boundary conditions in ocean models. Tellus, v. 50A, p. 348-367, 1998.

PAHNKE, K.; ZAHN, R. Southern Hemisphere Water Mass Conversion Linked with North Atlantic Climate Variability. Science, v. 307, p. 1741-1745, 2005.

PEIXOTO, J.; OORT, A. Physics of Climate. Spring-Verlag, $520 \mathrm{pp}, 1992$.

PELTIER, W. Ice age paleotopography. Science, v. 265, p. 195-201, 1994.

PELTIER, W.; VETTORETTI, G.; STASTNA, M. Atlantic meridional overturning and climate response to Arctic ocean freshening. Geophysical Research Letters, v. 33, L06713, doi:10.1029/2005GL025251, 2006.

RIND, D.; DEMENOCAL, P.; RUSSELL, G.; SHETH, S.; COLLINS, D.; SCHMIDT, G.; TELLER, J. Effects of glacial meltwater in the GISS Coupled Atmosphere-Ocean Model: Part I: North Atlantic Deep Water Response. Journal of Geophysical Research, v. 106, p. 27335-27354, 2001a.

RIND, D.; RUSSELL, G.; SCHMIDT, G.; SHETH, S.; COLLINS, D.; DEMENOCAL, P.; TELLER, J. Effects of glacial meltwater in the GISS Coupled Atmosphere-Ocean Model: Part II: A bi-polar seesaw in Atlantic Deep Water production. Journal of Geophysical Research, v. 106, p. 27355-27366, 2001b.

SCHÄFER, P.; RITZRAU, W.; SCHLÜTER, M.; THIEDE, J. Fundamental modes and abrupt changes in North Atlantic circulation and climate over the last $60 \mathrm{ky}$ - Concepts, reconstructions and numerical modeling, Springer Verlag, Berlin, p. 365-410, 2001.

SCHILLER, A.; MIKOLAJEWICZ, U.; VOSS, R. The stability of the North Atlantic thermohaline circulation in a coupled ocean-atmosphere general circulation model. Climate Dynamics, v. 13, p. 325-347, 1997.

SCHMITT, R.; BOGDEN, P.; DORMAN, C. Evaporation minus precipitation and density flux for the North Atlantic. Journal of Physical Oceanography, p. 1208-1221, 1989.
SCHNEIDER, S. H. Encyclopedia of Climate and Weather. Oxford University Press, p. 278-283, 1996.

SCHULZ, H.; VON RAD, U.; ERLENKEUSER, H. Correlation between Arabian Sea and Greenland climate oscillations of the past 111,000 years. Nature, v. 393, p. 54-57, 1998.

SEIDOV, D.; BARRON, E.; HAUPT, B. Meltwater and the global conveyor: northern versus southern connections. Global Planetary Change, v. 30, p. 257-270, 2001.

SPEER, K.; TZIPERMAN, E. Rates of water mass formation in the North Atlantic Ocean. Journal of Physical Oceanography, v. 22, p. 94-104, 1992.

STOCKER, T. The seesaw effect. Science, v. 286, p. 61-62, 1998.

STOCKER, T.; JOHNSEN, S. A minimum thermodynamic model for a bipolar seesaw. Paleoceanography, v. 18, doi:10.1029/2003PA000920, 2003.

TALLEY, D.; REID, L.; ROBBINS, E. Data-based meridional overturning streamfunctions for the global ocean. Journal of Climate, v. 16, p. 3213-3226, 2003.

TIMMERMANN, A.; JUSTINO, F.; JIN, F.; KREBS, U.; GOOSSE, H. Surface temperature control in the North and tropical Pacific during the last glacial maximum. Climate Dynamics, v. 23, p. 353-370, 2004.

TIMMERMANN, A.; KREBS, U.; JUSTINO, F.; GOOSSE, H.; IVANOCHKO, T. Mechanism for millenial-scale global synchronization during the last glacial period. Paleoceanography, v. 20, doi:10.1029/2004PA001090, 2005.

TRENBERTH, K.; CARON, J. Estimates of meridional atmosphere and ocean heat transports. Journal of Climate, v. 14, p. 3433-3443, 2001.

VEUM, T.; JANSEN, E.; ARNOLD, M.; BEYER, I.; DUPLESSY, J. Water mass exchange between the North Atlantic and the Norwegian Sea during the past 28,000 years. Nature, v. 356, p. 783-785, 1992.

WANG, P. Response of Western Pacific marginal seas to glacial cycles: paleoceanographic and sedimentological features. Marine Geology, v. 156, p. 5-39, 1999. 